\title{
Treasury Management of Small and Medium-Sized Enterprises
}

\author{
Renata I. Mikan $^{\# 1}$, Raúl J. Martelo ${ }^{* 2}$, Piedad M. Montero ${ }^{* 3}$ \\ \# Independent Researcher, Riohacha, La Guajira, Colombia \\ ${ }^{1}$ renomikaiguara@hotmail.com \\ * Faculty of Engineering, University of Cartagena, Cartagena, Bolívar, Colombia. \\ ${ }^{2}$ rmartelog1@unicartagena.edu.co \\ 3 pmargaritamontero@unicartagena.edu.co
}

\begin{abstract}
The objective of this research was to analyze treasury management in small and medium sized companies in Colombian - Venezuela. The analysis provided the interpretation of the financial management of these countries, which gives SMEs the possibility of optimizing their financial operations to measure and expand the scope of objectives and goals towards the production of benefits. The research carried out was of a quantitative nature, due to the fact that data or variables were collected and assigned a value to establish measurement points and perform computations. Considering the above, the results obtained showed that the organization uses treasury management to coordinate activities that allow achieving optimal results in the company and contribute to maintain a good liquidity in the face of imperfections in the collection and payment systems.
\end{abstract}

Keyword - Cash, Finances, Decisions Making, SMEs, Liquidity

\section{INTRODUCTION}

The globalization of the economy and the accelerated increase in competitiveness in the world market [1], require effective management of the financial system of SMEs [2]. Due to the growth of the economic sector, the financial system is favorably affected, which increases the opportunities to acquire liquidity or finance investments [2]. Therefore, the need arises to create a treasury that is responsible for managing, organizing and controlling the operations associated with cash or monetary flow and considering the recommendation of [4] that other entities should not be allowed to have access to bank accounts or to the flow of money from a company without the supervision of the treasury.

Treasury has an important role in the financial system, since it aims to evaluate the management of a company's cash both in the short and long term and ensure sufficient liquidity to operate [5]. In this way, it is inferred that an efficient administration of cash requires that the budget be broken down monthly, weekly or even daily [6]. The above leads to obtain a holistic management in the treasuries of SMEs, due to the financial dimension that allows decisions to be made in advance.

Considering what has been described, the application of treasury management in SMEs is of great importance because the management model of the monetary funds of the company is based on an exact distribution of the appropriate management objects, which include capital, assets and financial resources [7]. In addition, a good structure of treasury management leads to the success of a company [8].

However, small and medium enterprises have problems such as: high interest rates [9], economic recession [10], progressive devaluation [11] and rising inflation [12], which generate higher costs in obtaining financial resources reflected in the price of the products offered. That is why, in the current economy, the main role of management is aimed at the management of continuous change, forcing managers to be promoters and change actors.

For this reason, the objective of this research was to analyze treasury management in small and medium sized companies in Colombia - Venezuela. The above, serves as a tool for making financial decisions in this type of companies, which allows to strengthen the strategies applied in the administration of resources and carry out a better treasury management.

\section{Methodology}

The present investigation is of quantitative type with non-experimental descriptive cross-sectional design. Quantitative, because data or variables are collected and assigned a value to establish measurement points and perform calculations; not experimental, since the research was carried out without manipulating, directing or intervening in the variables or phenomena studied; cross-sectional, due to the fact that data are gathered at a specific moment of the inquiry and the relationship between the variables is analyzed; descriptive, because we want to measure, evaluate or collect information in an autonomous or united way about the variables to study [13] [14]. 
The dimensions and indicators of the Treasury Management study variable were identified, based on concepts such as: cash, cash flow, cash management process, operational activities, investments, financing, among others. The dimensions and indicators considered for this research are shown in Table 1.

TABLE I. Dimensions and indicators of treasury management

\begin{tabular}{|c|c|c|}
\hline VARIABLES & DIMENSIONS & INDICATORS \\
\hline \multirow{12}{*}{$\begin{array}{c}\text { Treasury } \\
\text { Management }\end{array}$} & \multirow{2}{*}{ Treasury management process } & Collection Flow \\
\hline & & Payment flow \\
\hline & \multirow{3}{*}{ Cash management } & Cover accounts payable \\
\hline & & Use of the Inventory, as quickly as possible \\
\hline & & Increased turnover of raw material \\
\hline & \multirow{3}{*}{ Cash Flow } & Operational activities \\
\hline & & Investment activities \\
\hline & & Financing activities \\
\hline & \multirow{4}{*}{ Financing strategies } & Commercial credit \\
\hline & & Credit lines \\
\hline & & Inventory financing \\
\hline & & Bank credit \\
\hline
\end{tabular}

\section{A. Population and sample}

The population was formed by 18 administrators in charge of the treasury area in small and medium-sized companies in Colombia and Venezuela. Which was distributed as follows: two from Visión Consorcia S.A.S., two from Interaseo S.A. E.S.P., three from Compulago S.A.S., two from Sertempo, one from Royal Films S.A.S., two from Agencia Selinger C.A., one from Alfarería San Francisco (ALFASUR), two from Almacenadora de Occidente S.A., one from Avícola Aeropuerto C.A. and two of Biokit de Maracaibo. Because the entire population could be surveyed, a census was applied [15].

\section{B. Data collection}

The technique used for the collection of information was the survey. This was measured using the data collection instrument Questionnaire, which was structured by 36 items organized as follows: management process (items 1 to 6); cash management (items 7 to 15); cash flow (items 16 to 24) and financing strategies (items 25 to 36). For the design of the opinion scale questionnaire, the Likert scale was used as criteria, where the items were presented in a 4-point format for the analysis alternatives: Always (4), Almost Always (3), Almost Never (2) and Never (1).

\section{Validity and reliability of instrument}

The designed instrument was subjected to a content validation process through Expert Judgment. To do this, 5 experts were chosen in the subject of study, who was given a copy of the instrument with the objective of the research and the operationalization of the variable. The experts took into account each item of the instrument to guarantee the clarity, coherence and relevance of the same with the objective, dimension and indicator of the variable of inquiry.

On the other hand, the reliability of the instrument was determined through the use of a pilot test, which was applied to a sample of 10 treasury managers in other companies related to those studied. Reliability was determined through Cronbach's Alpha coefficient, using Formula 1.

$$
a=\frac{n}{n-1}\left(1-\frac{\sum s^{2} i}{S^{2} t}\right)
$$

Wherein:

$a=$ Coefficient

$n=$ Number of items

$S_{i}^{2}=$ Variance of instrument items

$S_{t}^{2}=$ Variance of the total scores.

Between 0.81 and 1.00: very high.

Between 0.61 and 0.80: high.

Between 0.41 and 0.60: moderate. 
Between 0.21 and 0.40: low.

Between 0.10 and 0.20: very low.

A coefficient of 0.94 was obtained, which was considered very reliable, since it is a value that is between 0.81 and 1.00 .

\section{Data analysis}

The information obtained through the application of the instrument was processed using descriptive statistics: frequency, percentage and arithmetic mean. After collecting and processing the information, the data were tabulated, performing their analysis according to the percentage relationship technique, where the values are converted to percentage. Subsequently, each study alternative was averaged, in order to establish possible similarities and dissimilarities between the opinions given by the persons investigated. In addition, to deepen the analysis, a scale was developed (Table 2) that facilitated the comparison of the results obtained and allowed to establish the behavior of the indicators, dimensions and variables under study, which helped to clarify the fulfillment of the objective of the investigation.

TABLE II. Scale for the statistical analysis of the mean

\begin{tabular}{|c|c|c|c|}
\hline Level & Interval & Category & Description \\
\hline 5 & $4.24-5.00$ & Very Favorable & The variable that is being analyzed is located within a very \\
high frequency.
\end{tabular}

\section{RESULTS}

This section presents the results obtained through the information provided by the subjects participating in the research according to the dimensions: Treasury management processes, cash management, cash flow and financing strategies.

For the first dimension, the data provided in the questionnaire were grouped and averaged to categorize them according to the scale, as shown in Table 3 in Colombia and Table 4 for Venezuela.

TABLE III. Dimension Treasury management processes in Colombia

\begin{tabular}{|c|cc|c|cc|c|cc|cc|c|c|}
\hline Response categories & Always5 & \multicolumn{2}{|c|}{$\begin{array}{c}\text { Almost } \\
\text { always4 }\end{array}$} & $\begin{array}{c}\text { Some } \\
\text { times3 }\end{array}$ & $\begin{array}{c}\text { Almost } \\
\text { never2 }\end{array}$ & Never1 & $\begin{array}{c}\text { Weighted } \\
\text { Average }\end{array}$ & Category \\
\hline Indicators & af & $\%$ & af & $\%$ & af & $\%$ & af & $\%$ & af & $\%$ & & \\
\hline Collection flow & 1 & 10.00 & 3 & 30.00 & 5 & 50.00 & 1 & 10.00 & -- & -- & 3.40 & $\begin{array}{c}\text { Moderately } \\
\text { Favorable }\end{array}$ \\
\hline Payment flow & 2 & 20.00 & 3 & 30.00 & 4 & 40.00 & 1 & 10.00 & -- & -- & 3.60 & Favorable \\
\hline Averages of the dimension & 1 & 15.00 & 3 & 30.00 & 5 & 45.00 & 1 & 10.00 & -- & -- & 3.50 & Favorable \\
\hline Average of the dimension & \multicolumn{10}{|c|}{3.50} \\
\hline Category & \multicolumn{10}{|c|}{ Favorable } \\
\hline
\end{tabular}

TABLE IV. Dimension Treasury management processes in Colombia

\begin{tabular}{|c|cc|cc|cc|cc|cc|c|c|c|}
\hline Response categories & Always5 & \multicolumn{2}{|c|}{$\begin{array}{c}\text { Almost } \\
\text { always4 }\end{array}$} & \multicolumn{2}{c|}{$\begin{array}{c}\text { Some } \\
\text { times3 }\end{array}$} & $\begin{array}{c}\text { Almost } \\
\text { never2 }\end{array}$ & Never1 & $\begin{array}{l}\text { Weighted } \\
\text { Average }\end{array}$ & Category \\
\hline Indicators & af & $\%$ & af & $\%$ & af & $\%$ & af & $\%$ & af & $\%$ & & \\
\hline Collection flow & 1 & 12.50 & 2 & 25.00 & 4 & 50.00 & 1 & 12.50 & -- & -- & 3.70 & Favorable \\
\hline Payment flow & 2 & 25.00 & 2 & 25.00 & 3 & 37.50 & 1 & 12.50 & -- & -- & 3.63 & Favorable \\
\hline $\begin{array}{c}\text { Averages of the } \\
\text { dimension }\end{array}$ & 1 & 18.75 & 2 & 25.00 & 4 & 43.75 & 1 & 12.50 & -- & -- & 3.67 & Favorable \\
\hline $\begin{array}{c}\text { Average of the } \\
\text { dimension }\end{array}$ & \multicolumn{11}{|c|}{3.67} \\
\hline Category & \multicolumn{11}{|c|}{ Favorable } \\
\hline
\end{tabular}


It is observed that Table 3 presents an average of 3.50, which locates the Treasury Management Processes dimension in Colombia in the Favorable category and Table 4 shows an average of 3.67, that is, that this dimension in Venezuela is also in the same category. From the above, it is shown that the organization uses treasury management to coordinate activities that achieve optimal results in the company and contribute to maintain a good liquidity against short-term payments. The above coincides with what was stated by [16], who states that management refers to the direction of actions that contribute to making decisions aimed at achieving the objectives set and measuring the results obtained to guide the action towards the permanent improvement of the system.

To compare the dimension studied with respect to both countries, the means obtained in each indicator were tabulated, as shown in Table 5.

TABLE V. Comparison of the means of the dimension Processes of treasury management Colombian-Venezuelan

\begin{tabular}{|c|cc|cc|}
\hline & \multicolumn{2}{|c|}{ COLOMBIA } & \multicolumn{2}{c|}{ VENEZUELA } \\
\hline Indicators & Arithmetic average & Category & Arithmetic average & Category \\
\hline Collection flow & 3.40 & Moderately Favorable & 3.70 & Favorable \\
\hline Payment flow & 3.60 & Favorable & 3.63 & Favorable \\
\hline Average & 3.50 & Favorable & 3.67 & Favorable \\
\hline
\end{tabular}

Treasury management processes in Colombian and Venezuelan SMEs show similarities, because the category defined by the average was Favorable, indicating that in both cases the processes that are carried out of treasury management are appropriate.

On the other hand, we analyzed the Cash Administration dimension in the SMEs of both nations. To study this dimension, the information acquired through the questionnaire was taken into account and the calculations were made to categorize it according to the scale, both in Colombian SMEs (Table 6) and Venezuelan SMEs (Table 7).

TABLE VI. Dimension Cash management in Colombia

\begin{tabular}{|c|c|c|c|c|c|c|c|c|c|}
\hline Response categories & \multicolumn{2}{|c|}{ Always5 } & \multicolumn{2}{|c|}{$\begin{array}{c}\text { Almost } \\
\text { always4 }\end{array}$} & $\begin{array}{c}\text { Some } \\
\text { times3 }\end{array}$ & $\begin{array}{l}\text { Almost } \\
\text { never2 }\end{array}$ & Never1 & \multirow[t]{2}{*}{$\begin{array}{l}\text { Weighted } \\
\text { Average }\end{array}$} & \multirow[t]{2}{*}{ Category } \\
\hline Indicators & af & $\%$ & af & $\%$ & af $\%$ & af $\%$ & af $\%$ & & \\
\hline Cover accounts payable & -- & -- & 1 & 10.00 & 330.00 & $\begin{array}{ll}3 & 30.00\end{array}$ & $\begin{array}{ll}3 & 30.00\end{array}$ & 2.20 & $\begin{array}{c}\text { Moderately } \\
\text { Favorable }\end{array}$ \\
\hline Use of the Inventory & 1 & 10.00 & 2 & 20.00 & $3 \quad 30.00$ & $3 \quad 30.00$ & $\begin{array}{ll}1 & 10.00\end{array}$ & 2.90 & $\begin{array}{l}\text { Moderately } \\
\text { Favorable }\end{array}$ \\
\hline $\begin{array}{l}\text { Increase in Rotation of } \\
\text { Raw Materials }\end{array}$ & 2 & 20.00 & 3 & 30.00 & $\begin{array}{ll}4 & 40.00\end{array}$ & $\begin{array}{ll}1 & 10.00\end{array}$ & -- & 3.70 & Favorable \\
\hline $\begin{array}{l}\text { Averages of the } \\
\text { dimension }\end{array}$ & 1 & 10.00 & 2 & 20.00 & $\begin{array}{ll}3 & 33.33\end{array}$ & 223.33 & $\begin{array}{ll}1 & 13.33\end{array}$ & 2.93 & $\begin{array}{c}\text { Moderately } \\
\text { Favorable }\end{array}$ \\
\hline Average of the dimension & \multicolumn{9}{|c|}{2.93} \\
\hline Category & \multicolumn{9}{|c|}{ Moderately Favorable } \\
\hline
\end{tabular}

TABLE VII. Dimension Cash management in Venezuela

\begin{tabular}{|c|c|c|cc|cc|cc|cc|cc|c|c|}
\hline Response categories & Always5 & $\begin{array}{c}\text { Almost } \\
\text { always4 }\end{array}$ & $\begin{array}{c}\text { Some } \\
\text { times3 }\end{array}$ & $\begin{array}{c}\text { Almost } \\
\text { never2 }\end{array}$ & Never1 & $\begin{array}{c}\text { Weighted } \\
\text { Average }\end{array}$ & Category \\
\hline Indicators & af & $\%$ & af & $\%$ & af & $\%$ & af & $\%$ & af & $\%$ & & \\
\hline Cover accounts payable & 1 & 12.50 & 1 & 12.50 & 1 & 12.50 & 3 & 37.50 & 2 & 25.00 & 2.50 & $\begin{array}{c}\text { Moderately } \\
\text { Favorable }\end{array}$ \\
\hline Use of the Inventory & -- & -- & 3 & 37.50 & 3 & 37.50 & 2 & 25.00 & -- & -- & 3.13 & $\begin{array}{c}\text { Moderately } \\
\text { Favorable }\end{array}$ \\
\hline $\begin{array}{c}\text { Increase in Rotation of } \\
\text { Raw Materials }\end{array}$ & 2 & 25.00 & 3 & 37.50 & 3 & 37.50 & -- & -- & -- & -- & 3.88 & Favorable \\
\hline \begin{tabular}{c} 
Averages of the dimension \\
\hline Average of the dimension
\end{tabular} & 1 & 12.50 & 2 & 29.17 & 2 & 29.17 & 2 & 20.83 & 1 & 8.33 & 3.17 & $\begin{array}{c}\text { Moderately } \\
\text { Favorable }\end{array}$ \\
\hline Category & \multicolumn{10}{|c|}{3.17} \\
\hline
\end{tabular}


It is contemplated that the Cash Administration dimension in Colombian and Venezuelan SMEs presents the same category, Moderately Favorable, because the average obtained in both cases is within the range $2.62-3.42$ of the scale. According to the above, it is understood that cash management is not carried out efficiently, due to the lack of liquidity financing of working capital through different sources generated by SMEs. In this regard, [17] it indicates that cash management is essential to detail the flow of cash in and out in order to preserve profitability and sustainability. It also considers that an inappropriate administration of cash leads to some companies not supervising their sales and income, which causes not having the necessary cash to satiate their expenses.

To make a comparison of the Cash Administration dimension with respect to both countries, the means obtained in each indicator were tabulated, as shown in Table 8.

TABLE VIII. Comparison of the means of the Administration dimension with cash Colombian - Venezuelan

\begin{tabular}{|c|cc|cc|}
\hline & \multicolumn{2}{|c|}{ COLOMBIA } & \multicolumn{2}{c|}{ VENEZUELA } \\
\hline Indicators & $\begin{array}{c}\text { Arithmetic } \\
\text { average }\end{array}$ & Category & $\begin{array}{c}\text { Arithmetic } \\
\text { average }\end{array}$ & Category \\
\hline Cover accounts payable & 2.20 & $\begin{array}{c}\text { Moderately } \\
\text { Favorable }\end{array}$ & 2.50 & $\begin{array}{c}\text { Moderately } \\
\text { Favorable }\end{array}$ \\
\hline Use of the Inventory & 2.90 & $\begin{array}{c}\text { Moderately } \\
\text { Favorable }\end{array}$ & 3.13 & $\begin{array}{c}\text { Moderately } \\
\text { Favorable }\end{array}$ \\
\hline Increase in Rotation of Raw Materials & 3.70 & Favorable & 3.88 & Favorable \\
\hline Average & 2.93 & $\begin{array}{c}\text { Moderately } \\
\text { Favorable }\end{array}$ & 3.17 & $\begin{array}{c}\text { Moderately } \\
\text { Favorable }\end{array}$ \\
\hline
\end{tabular}

The administration of cash in Colombian and Venezuelan SMEs is similar, since the category defined by the average in both cases was Moderately favorable, which indicates that the administration of working capital is not very effective in the studied SMEs.

In the same way, the Cash Flow dimension in the SMEs of both countries was observed. The study of this dimension was carried out through the processing of the data obtained in the questionnaire to categorize the SMEs both Colombian (Table 9) and Venezuelan (Table 10) according to a range of the scale and then make a comparison between them.

TABLE IX. Dimension Cash flow in Colombia

\begin{tabular}{|l|cc|cc|cc|cc|cc|c|c|c|}
\hline \multicolumn{1}{|c|}{ Response categories } & Always5 & \multicolumn{2}{|c|}{$\begin{array}{c}\text { Almost } \\
\text { always4 }\end{array}$} & \multicolumn{2}{c|}{$\begin{array}{c}\text { Some } \\
\text { times3 }\end{array}$} & \multicolumn{2}{|c|}{$\begin{array}{c}\text { Almost } \\
\text { never2 }\end{array}$} & Never1 & $\begin{array}{c}\text { Weighted } \\
\text { Average }\end{array}$ & Category \\
\hline \multicolumn{1}{|c|}{ Indicators } & af & $\%$ & af & $\%$ & af & $\%$ & af & $\%$ & af & $\%$ & & \\
\hline Operational activities & 3 & 30.00 & 3 & 30.00 & 3 & 30.00 & 1 & 10.00 & -- & -- & 3.80 & Favorable \\
\hline Investment activities & 1 & 10.00 & 2 & 20.00 & 5 & 50.00 & 2 & 20.00 & -- & -- & 3.20 & $\begin{array}{c}\text { Moderately } \\
\text { Favorable }\end{array}$ \\
\hline Financing Activities & 3 & 30.00 & 2 & 20.00 & 4 & 40.00 & 1 & 10.00 & -- & -- & 3.40 & $\begin{array}{c}\text { Moderately } \\
\text { Favorable }\end{array}$ \\
\hline Averages of the dimension & 2 & 23.33 & 2 & 23.33 & 4 & 40.00 & 1 & 13.33 & -- & -- & 3.47 & Favorable \\
\hline Average of the dimension & \multicolumn{10}{|c|}{3.47} \\
\hline Category & \multicolumn{110}{|c|}{ Favorable } \\
\hline
\end{tabular}

TABLE X. Dimension Cash flow in Venezuela

\begin{tabular}{|l|cc|c|cc|cc|cc|c|c|c|}
\hline \multicolumn{1}{|c|}{ Response categories } & Always5 & \multicolumn{2}{|c|}{$\begin{array}{c}\text { Almost } \\
\text { always4 }\end{array}$} & \multicolumn{2}{c|}{$\begin{array}{c}\text { Some } \\
\text { times3 }\end{array}$} & $\begin{array}{c}\text { Almost } \\
\text { never2 }\end{array}$ & Never1 & $\begin{array}{c}\text { Weighted } \\
\text { Average }\end{array}$ & Category \\
\hline \multicolumn{1}{|c|}{ Indicators } & af & $\%$ & af & $\%$ & af & $\%$ & af & $\%$ & af & $\%$ & & \\
\hline Operational activities & 2 & 25,00 & 3 & 37,50 & 2 & 25,00 & 1 & 12,50 & -- & -- & 3,75 & Favorable \\
\hline Investment activities & 1 & 12,50 & 2 & 25,00 & 4 & 50,00 & 1 & 12,50 & -- & -- & 3,38 & $\begin{array}{c}\text { Moderately } \\
\text { Favorable }\end{array}$ \\
\hline Financing Activities & 2 & 25,00 & 2 & 25,00 & 3 & 37,50 & 1 & 12,50 & -- & -- & 3,63 & Favorable \\
\hline Averages of the dimension & 2 & 20,83 & 2 & 29,17 & 3 & 37,50 & 1 & 12,50 & -- & -- & 3,59 & Favorable \\
\hline Average of the dimension & \multicolumn{10}{|c|}{3.59} \\
\hline \multicolumn{110}{|c|}{ Category } & \multicolumn{11}{|c|}{ Favorable } \\
\hline
\end{tabular}


It is observed that the Cash Flow dimension in Colombian-Venezuelan SMEs was identified with the same category, Favorable, because the average obtained in both cases is within the range of $3.43-4.23$ on the scale. Based on the above, it is demonstrated that the administrators carry out operational, investment and financing activities, with the purpose of reducing the cash requirements of the company through imperfections in the collection and payment systems. According to [18], the fundamental objective of cash flow is to provide information on collections and payments of cash, financing and the investment activities of the company.

The Cash Flow dimension between the two countries was compared, where the means obtained in each indicator were tabulated, as shown in Table 11.

TABLE XI. Comparison of the means of the Colombian - Venezuelan cash flow dimension

\begin{tabular}{|c|c|c|c|c|}
\hline & \multicolumn{2}{|c|}{ COLOMBIA } & \multicolumn{2}{|c|}{ VENEZUELA } \\
\hline Indicators & Arithmetic average & Category & Arithmetic average & Category \\
\hline Investment activities & 3.80 & Favorable & 3.75 & Favorable \\
\hline Financing Activities & 3.20 & $\begin{array}{c}\text { Moderately } \\
\text { Favorable }\end{array}$ & 3.38 & $\begin{array}{c}\text { Moderately } \\
\text { Favorable }\end{array}$ \\
\hline Averages of the dimension & 3.40 & $\begin{array}{c}\text { Moderately } \\
\text { Favorable }\end{array}$ & 3.63 & Favorable \\
\hline Average & 3.47 & Favorable & 3.59 & Favorable \\
\hline
\end{tabular}

When comparing the Cash Flow in Colombian - Venezuelan SMEs, it was observed that the means were located in the same interval of the scale, that is, Favorable. This shows that the cash flow is considered necessary and important in the SMEs of the two nations.

Finally, the Financing Strategies dimension in Colombian - Venezuelan SMEs was studied, where the information provided in the questionnaire was taken into account to categorize Colombian SMEs (Table 12) and Venezuelan SMEs (Table 13) according to a scale interval and then compare them.

TABLE XII. Dimension Financing Strategies in Colombia

\begin{tabular}{|c|c|c|c|c|c|c|c|c|c|c|c|c|}
\hline Response categories & \multicolumn{2}{|c|}{ Always5 } & \multicolumn{2}{|c|}{$\begin{array}{c}\text { Almost } \\
\text { always4 }\end{array}$} & \multicolumn{2}{|c|}{$\begin{array}{c}\text { Some } \\
\text { times3 }\end{array}$} & \multicolumn{2}{|c|}{ Almost never2 } & \multicolumn{2}{|c|}{ Never1 } & \multirow{2}{*}{\begin{tabular}{|c|} 
Weighted \\
Average
\end{tabular}} & \multirow{2}{*}{$\begin{array}{c}\text { Category } \\
\%\end{array}$} \\
\hline Indicators & af & $\%$ & af & $\%$ & af & $\%$ & af & Indicators & af & & & \\
\hline Commercial Credit & 2 & 20.00 & 2 & 30.00 & 4 & 40.00 & 2 & 20.00 & -- & -- & 3.40 & $\begin{array}{c}\text { Moderately } \\
\text { Favorable }\end{array}$ \\
\hline Credit line & 1 & 10.00 & 2 & 20.00 & 6 & 60.00 & 1 & 10.00 & -- & -- & 3.30 & $\begin{array}{c}\text { Moderately } \\
\text { Favorable }\end{array}$ \\
\hline Inventory Financing & 2 & 20.00 & 2 & 20.00 & 4 & 40.00 & 2 & 20.00 & -- & -- & 3.40 & $\begin{array}{c}\text { Moderately } \\
\text { Favorable }\end{array}$ \\
\hline Bank credit & 2 & 20.00 & 2 & 20.00 & 5 & 50 & 1 & 10.00 & & & 3.50 & Favorable \\
\hline Averages of the dimension & 2 & 17.50 & 2 & 23.33 & 5 & 47.50 & 2 & 20.00 & & -- & 3.40 & $\begin{array}{c}\text { Moderately } \\
\text { Favorable }\end{array}$ \\
\hline Average of the dimension & \multicolumn{12}{|c|}{3.40} \\
\hline Category & \multicolumn{12}{|c|}{ Moderately Favorable } \\
\hline
\end{tabular}

TABLE XIII. Dimension Financing Strategies in Venezuela

\begin{tabular}{|c|c|c|c|c|c|c|c|}
\hline Response categories & Always5 & $\begin{array}{l}\text { Almost } \\
\text { always4 }\end{array}$ & $\begin{array}{l}\text { Some } \\
\text { times3 }\end{array}$ & Almost never2 & Never1 & $\begin{array}{l}\text { Weighted } \\
\text { Average }\end{array}$ & Category \\
\hline Indicators & af & $\begin{array}{ll}\text { af } \quad \% \\
\end{array}$ & af $\%$ & af Indicators & af $\%$ & af & $\%$ \\
\hline Commercial Credit & $2 \quad 25.00$ & 225.00 & 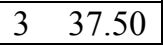 & 12.50 & $---\quad--$ & 3.62 & Favorable \\
\hline Credit line & $1 \quad 12.50$ & $2 \quad 25.00$ & $4 \quad 50.00$ & 12.50 & $--\quad--$ & 3.38 & $\begin{array}{l}\text { Moderately } \\
\text { Favorable }\end{array}$ \\
\hline Inventory Financing & $1 \quad 12.50$ & $2 \quad 25.00$ & $3 \quad 37.50$ & 25.00 & $--\quad--$ & 3.25 & $\begin{array}{c}\text { Moderately } \\
\text { Favorable }\end{array}$ \\
\hline Bank credit & $\begin{array}{ll}1 & 12.50 \\
\end{array}$ & $\begin{array}{ll}2 & 25.00 \\
\end{array}$ & $\begin{array}{ll}3 & 37.50 \\
\end{array}$ & 25.00 & & 3.25 & Favorable \\
\hline $\begin{array}{l}\text { Averages of the } \\
\text { dimension }\end{array}$ & $1 \quad 15.62$ & 225.00 & 340.63 & 18.75 & -- & 3.35 & $\begin{array}{c}\text { Moderately } \\
\text { Favorable }\end{array}$ \\
\hline Average of the dimension & \multicolumn{7}{|c|}{3.35} \\
\hline Category & \multicolumn{7}{|c|}{ Moderately Favorable } \\
\hline
\end{tabular}


It is shown that the dimension Financing Strategies in Colombian -Venezuelan SMEs are identified with the category Moderately Favorable of the range of the scale, because the means obtained in both cases were within the range $2.62-3.42$. Based on the foregoing, it is stated that the treasury managers in Colombian - Venezuelan SMEs moderately use commercial credit, line of credit, inventory financing and bank credit to manage their immediate investments. However, [19] he argued that decisions regarding investment in the treasury area should be carefully examined in order to choose the most profitable, which is obtained by considering the risk and profitability in the investment plan that increases the value of the shares. In addition, [20] he proposed that financing strategies are related to the working capital of small and medium-sized enterprises and the financial soundness of these, which allows profitability-oriented development through the strategic management of resources in function of financing, investments, accounts payable, capital flow, among others.

In comparison with the financing strategies dimension of the Colombian - Venezuelan SMEs, the results shown in Table 14 were obtained, which shows the distribution of the means of the indicators of this dimension, where very similar values are contemplated.

TABLE XIV. Dimension Financing Strategies in Colombia

\begin{tabular}{|c|cc|cc|}
\hline \multicolumn{1}{|c|}{ Indicators } & \multicolumn{2}{|c|}{ COLOMBIA } & \multicolumn{2}{c|}{ VENEZUELA } \\
\hline Commercial Credit & Arithmetic average & Category & Arithmetic average & Category \\
\hline Credit line & 3.40 & $\begin{array}{c}\text { Moderately } \\
\text { Favorable }\end{array}$ & 3.62 & Favorable \\
\hline Inventory Financing & 3.30 & $\begin{array}{c}\text { Moderately } \\
\text { Favorable }\end{array}$ & 3.38 & $\begin{array}{c}\text { Moderately } \\
\text { Favorable }\end{array}$ \\
\hline Bank credit & 3.50 & $\begin{array}{c}\text { Moderately } \\
\text { Favorable }\end{array}$ & 3.25 & $\begin{array}{c}\text { Moderately } \\
\text { Favorable }\end{array}$ \\
\hline Average & 3.40 & $\begin{array}{c}\text { Moderately } \\
\text { Favorable }\end{array}$ & 3.25 & $\begin{array}{c}\text { Moderately } \\
\text { Favorable }\end{array}$ \\
\hline
\end{tabular}

The analysis and interpretation of the results allow us to infer that the management processes of the Colombian - Venezuelan SMes present a Favorable category in treasury management, since the actions aim at the constant improvement of the company, that is, the management of the Treasury that is carried in the companies studied is adequate. However, there is not enough recourse to satisfy the company's current operations.

Therefore, it is suggested to Colombian - Venezuelan SMEs to have bank credit to finance their working capital, as well as to establish rules and controls in cash management that allow determining the necessary liquidity of the company, in order to maintain survival.

\section{IV.CONCLUSION}

The results obtained in the study of the management of treasuries in the small and medium companies of the Colombia - Venezuela, produced the following conclusions:

i) The investigation made it possible to determine that treasury management in Colombian - Venezuelan SMEs have similarities in aspects such as: Treasury management processes, cash management, cash flow and financing strategies, since they present a trend favorable of the actions towards the permanent improvement of the company.

ii) Performing treasury management processes allowed the administrators of the Colombian - Venezuelan SMEs to make good use of the collection and payment flow processes in order to achieve the financial objectives and develop the business capital.

iii) The administration of cash in Colombian - Venezuelan SMEs was little used in treasury management, because the administrators scarcely apply the realization of commercial operations for the amortization of the acquired responsibilities and lack of sources of income for the liquidity financing of the working capital

iv) Determine the cash flow in the cash management of Colombian - Venezuelan SMEs, showed weaknesses in the realization of investment activities, transactions related to money loans, sales of investments. Likewise, the risk and profitability in the investment project are not taken into account in order to increase the company's shares. 
v) Establish financing strategies in treasury management applied to SMEs in Venezuela, provide a solid base of operational capital flow and produce sustainability for the long-term development of companies.

\section{REFERENCES}

[1] N. Green, and E. J. Blakely, Planning local economic development: Theory and practice. California: Sage Publications, 2017.

[2] H. Karadag, "Financial Management Challenges In Small and Medium - Sized Enterprises: A Strategic Management Approach," Emerging Markets Journal, vol. 5, no. 1, pp. 25-40, 2015.

[3] K. Menyah, S. Nazlioglu and Y. Wolde-Rufael, "Financial development, trade openness and economic growth in African countries: New insights from a panel causality approach,” Economic Modelling, vol. 37, pp. 386-394, 2014

[4] T. R. Salman, and M. A. Adeseye, "Treasury Single Account and Fund Management in Nigeria: A Perception of Accounting Practitioners in Ado - Ekiti Metropolis,” KIU Journal of Humaniti, vol. 2, no. 1, pp. 19-32, 2017.

[5] J. Blach, M. Wieczorek-Kosmala, M. Gorczynska and A. Dos, "Innovations in Liquidity Management-the Potential of Corporate Treasury," Journal of Economics \& Management, vol. 18, pp. 209-224, 2014.

[6] E. Twineyo, The Basics of Business Management - Vol I. Leadership, Financial Management and Economics. Bookboon, 2017.

[7] M. O. Kuzheliev, D. M. Zherlitsyn and M. O. Zhytar, "Formalization of Dynamic Relations between Enterprise Financial Indicators," Practical Science Edition "Independent Auditor", vol. 2, no. 16, pp. 18-26, 2016.

[8] D. C. Solomon, and I. A. Bucur, "Aspects of Financial Equilibrium Analysis and Its Implications in Management Decisions," Studies and Scientific Researches, no. 18, pp. 221-230, 2013.

[9] M. Günerergin, Ş. Penbek and. D. Zaptçioğlu, "Exploring the Problems and Advantages of Turkish SMEs for Sustainability," Procedia - Social and Behavioral Sciences, vol. 58, pp. 244-251, 2012.

[10] R. Pal, H., Torstensson, and H. Mattila, "Antecedents of organizational resilience in economic crises — an empirical study of Swedish textile and clothing SMEs," Int. J. Production Economics, vol. 147, pp. 410-428, 2014.

[11] G. Ulian, and M. Mirzac, "Ways to Overcome the Constraints through Strategic Development of Support System for Financing Small and Medium Business," Theoretical and scientifical journal, vol. 1, pp. 61-67, 2015.

[12] M. Sghair, and J. Aston, "The Impact of Various Economic Factors in accessing Finance within the Business Sector: Case s from UK Financial Services Companies," International Journal of Applied Business and Management Studies, vol. 2, no. 1, pp. 16-25, 2017.

[13] P. Leavy, Research Design: Quantitative, Qualitative, Mixed Methods, Arts-Dased, and Community-Based Participatory Research Approaches. New York: The Guilford Press, 2017.

[14] K. S. Bordens, and B. B. Abbott, Research Design and Methods: A Process Approach. New York: McGraw-Hill Education, 2018.

[15] B. Beins, and M. McCarthy, Research Methods and Statistics. United States of America: Pearson education Inc., 2012.

[16] F. Sánchez, "Environmental management territorial premises," AZIMUT, Journal of Topography, vol. 1, pp. 73-85, 2007.

[17] N. N. Ahmad, "Cash management practices in micro and small businesses in Malaysia," Journal of Education and Social Sciences, no. 4, 2016.

[18] R. F. Meigs, J. Williams, S. Haka and M. S. Bettner, Accounting: the Basis for Business Decisions, 11th edition. McGraw-Hill, 2000.

[19] S. E. Bolten, Managerial Finance: Principles and Practice. Houghton Mifflin, 1976.

[20] L. Gitman, and C. Zutter, Principles of Managerial Finance, Brief, 6th edition. Pearson, 2012.

\section{AUTHOR PROFILE}

Renata I. Mikan works as independent researcher (Colombia). Mrs. Mikan completed her magister from University of La Guajira (Colombia). Mrs. Mikan completed her undergraduate in University of La Guajira.

Raul J. Martelo works as full-time professor at the University of Cartagena (Colombia). Mr. Martelo completed his magister from Industrial University of Santander (Colombia). Mr. Martelo completed his undergraduate in Systems Engineering at the Industrial University of Santander.

Piedad M. Montero works as full-time professor in the University of Cartagena (Colombia). Mrs. Montero completed her doctorate from Rafael Belloso Chacin University (Venezuela). Mrs. Montero completed her undergraduate in Food Engineering at the University of Cartagena. 